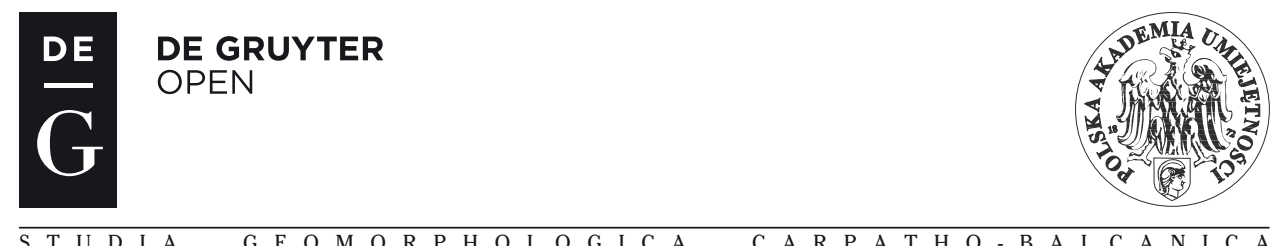

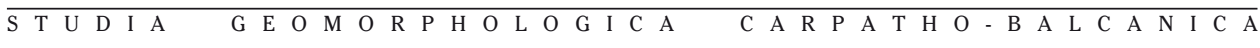

DOI $10.2478 / \mathrm{sgcb}-2013-0002$

\title{
SLOPE TRANSFORMATION WITHIN TOURIST FOOTPATHS IN THE WESTERN TATRA MOUNTAINS
}

\begin{abstract}
The aim of this paper is to determine slope transformation within tourist footpaths above the timberline on the north- and south-facing slopes of the Western Tatra Mountains. To characterize slope transformation within footpaths I applied geomorphological mapping. Differences in the effects of relief transformation due to natural processes on the north- and south-facing slopes were precisely determined based on test surfaces established on footpaths and slopes unaffected by human activity. The study indicated significant differences in the transformation of slope relief in the study area, related mostly to the disproportions in the intensity of tourist traffic and variability of natural conditions. The study also revealed a diversity in morphogenetic processes acting within tourist footpaths on the north-facing and south-facing slopes of the Western Tatra Mountains.
\end{abstract}

Key words: the Western Tatra Mountains, morphogenetic processes, geomorphological mapping, tourist footpaths, tourist traffic, geoecological belts

\section{INTRODUCTION}

Differences in relief transformation on north-facing and south-facing slopes and significant asymmetry in relief transformations between geoecological belts can be observed in several mountain areas in the world (Stocker 1979, 2003; $\mathrm{Rech}$ et al. 2001). The occurrence and intensity of morphogenetic processes in high-mountain areas can be limited to the forest belt or to the crionival belt, as documented by several authors (e.g. Kotarba, Starkel 1972; Kot a r b a 1976, 1984, 1992, 2002; Midriak 1983, 1996; Stankoviansky, Midriak 1998). Numerous studies of morphogenetic processes underscore the significant impact of asymmetry in relation to their activity and the resultant relief diversity on slopes with different aspect, especially $\mathrm{N}$ and S (Kotarba 1976, 1984; Stocker 1979, 2003; Kaszowski 1985; Rączkowska 1999, 2007; Kotarba, Długos z 2010). A. Kotarba (1984) emphasizes that the differences in the occurrence and course of morphogenetic processes on the slopes with opposite aspect within one geoecological belt may be greater than the differences due to climatic variability between adjacent belts. 
Protected areas belong to the most valuable natural areas within which one of the main tasks is to maintain the stability of natural ecosystems. Footpaths running on slopes are the main areas of human impact on nature areas under strict protection.

Mass tourism in protected areas causes the initiation and acceleration of morphogenetic processes, which is reflected in numerous polygenetic forms on slope footpaths. Therefore long-term studies are needed to identify the processes leading to most intensive and irreversible transformation of slope relief within footpaths, especially in valuable protected areas. Such studies are especially important in areas with a very high concentration of tourists in a small area, as for example in the Tatra Mountains. In comparison to other national parks in Europe, the Tatra National Park is one of the smaller parks but with a very high intensity of tourist traffic. Based on the findings of J. Pociask-Kartec zka et al. (2008) the number of visitors to the Tatra National Park exceeds 2 million per year, while in the significantly larger Alpine national parks the average number of tourists approaches only 0.7 million per year.

\section{STUDY AREA}

The analyzed footpaths are located in the valleys of Chochołowska, Jarząbcza and Starorobociańska in the northern part and Jamnicka and Račkova in the southern part of the study area (Fig. 1). The total length of the studied footpaths, accessible only to tourist traffic, is $44 \mathrm{~km}$. The study footpaths are located above the timberline (Fig. 1) in the subalpine and alpine geological belts $(18 \mathrm{~km}$ and $26 \mathrm{~km}$ of the total footpath length, respectively). All study footpaths are located in the crystalline part of the Tatra massif and run on granitoids and metamorphic rocks.

In the study area climatic conditions are varied (Tab. 1). The average annual precipitation in the north part of the study area is between $1200 \mathrm{~mm}$ and over $2000 \mathrm{~mm}$ (Niedźwiedź 1992), while in the southern part it is significantly lower and ranges from $800 \mathrm{~mm}$ to approx. $2000 \mathrm{~mm}$ ( $\mathrm{a} \mathrm{j} \mathrm{czak} \mathrm{2006).} \mathrm{Four}$ morphogenetic seasons were distinguished in the study area: nival, niveopluvial, pluvial and pluvionival (K ł a p a 1980).

The highest activity of morphogenetic processes occurs in the shortest, niveopluvial season, from April to June. The lowest activity of morphogenetic processes occurs in the longest, nival season due to the insulation of the slope surface provided by snow cover. The intensity of slope transformation during the year is dependent on intra-annual variability of climatic conditions. However, slopes with very similar climatic conditions may be transformed differently. One of the most important reasons for such differences is human activity. 


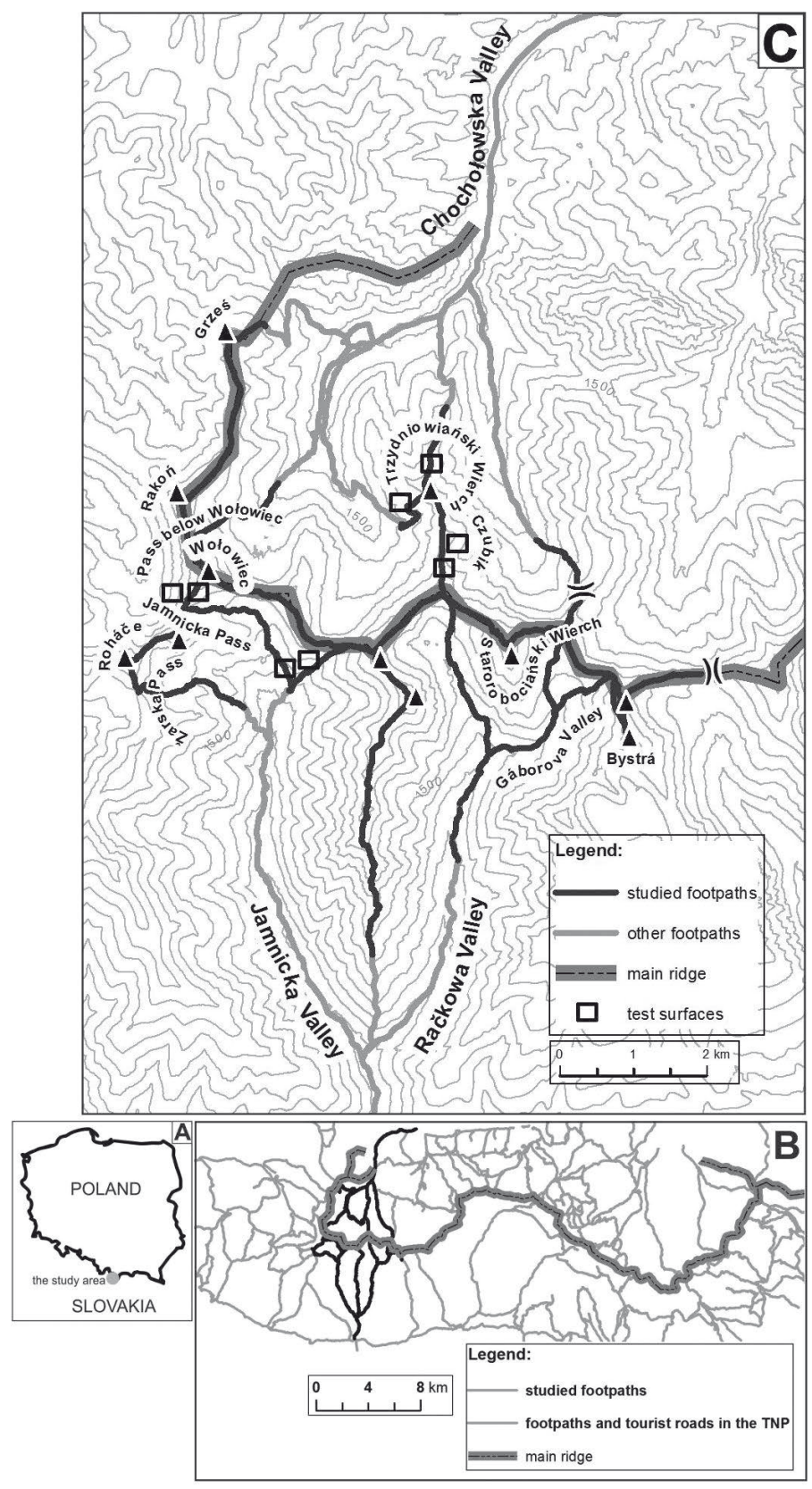

Fig. 1. The study area. A - location of the study area in Poland and Slovakia, B - location of the studied footpaths in the Polish and Slovak parts of the Tatra National Park (TNP), $\mathrm{C}$ - the studied footpaths 
Table 1

The climatic conditions in the study area based on M. He s s (1974), B. I z m a ił o w (1984)

\begin{tabular}{|l|c|c|}
\hline \multicolumn{1}{|c|}{ Climatic conditions (at $1700 \mathrm{~m}$ a.s.l): } & North-facing-slope & South-facing slope \\
\hline Number of days with snow cover & 217 days & 189 days \\
\hline Mean annual temperature & $+0,8^{\circ} \mathrm{C}$ & $+1,8^{\circ} \mathrm{C}$ \\
\hline $\begin{array}{l}\text { Number of days with temperature } \\
\text { below } 0^{\circ} \mathrm{C}\end{array}$ & 124 days & 95 days \\
\hline $\begin{array}{l}\text { Number of days with active wind, } \\
\text { with speeds over } 5 \mathrm{~m}^{*} \mathrm{~s}^{-1}\end{array}$ & \multicolumn{2}{|c|}{ from 20 to 200 days per year } \\
\hline
\end{tabular}

\section{METHODOLOGY}

In order to determine the effects of morphogenetic processes on footpaths running on slopes and ridges I used geomorphological mapping, conducted on topographical maps at 1:10000 scale. A special form for geomorphological mapping of footpaths and tourist roads was used. The study footpaths were divided into geomorphologically homogenious sections; the uniform footpath sections were further divided into sub-sections based on footpath width, surface type and location within larger landforms. The selected footpath sections were marked with GPS (Garmin 60-CSx). Based on geomorphological mapping I identified 335 uniform footpath sub-sections in the subalpine and alpine belts.

In order to determine and compare the effects of processes in subalpine and alpine belts on north- and south-facing slopes I established test surfaces on footpaths running on slopes and on slopes without any current human activity. I established eight test surfaces, four on the northern slopes in the Polish part of the Tatra National Park and four on southern slopes in the Slovak part. The part of this study based on test surfaces was conducted from 2007 to 2011. The size of every test surface, marked with metal rods, was about $4 \mathrm{~m}^{2}$. All test surfaces were located above the timberline, on slopes with a $15-20^{\circ}$ inclination. Each test site was repeatedly surveyed with cross-profile levelling carried out in the upper and lower part of each test surface, 2-4 times a year. The comparison of changes in cross-profiles was made based on a formula used by other researchers in different mountain areas in the world (Fig. 2) (Cole 1983; Ha m mitt, Jewell 2000).

This formula is as follows:

$$
A=\frac{\left(V_{1}+V_{2}\right)+\left(V_{2}+V_{3}\right)+\left(V_{3}+V_{4}\right)+(V n-1+V n)}{2} * L
$$

$A$ - area of incision within footpaths (the profile surface area on figures) 
$V_{1} \ldots V n-V_{1}$ (incision depth on footpaths from the first fixed point - initial measurement $\left.V_{1}\right)$

$L$ - (horizontal distance between the measurements)

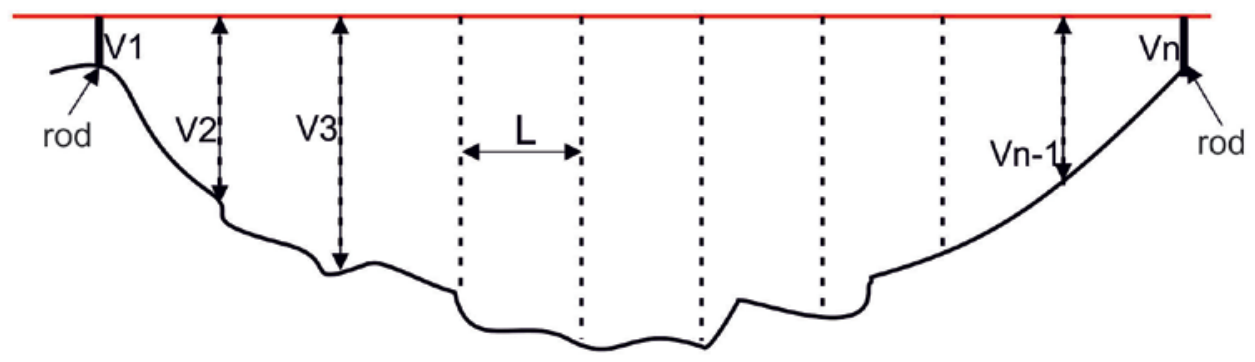

Fig. 2. Schematic of the cross profile used for area calculations within test surfaces

I took comparative photos of each test area from one fixed point. This documentation allowed me to determine the differences in relief transformation depending on the slope aspect and on whether the area is affected by foot traffic. Moreover, studies based on test surfaces on slope footpaths and slopes without human activity allowed for the identification of the impact of tourist traffic on the activity and effects of natural processes.

The research was also supplemented by measurements of tourist traffic carried out with two pyroelectric sensors (tourist counters) from June to $\mathrm{Au}-$ gust in 2011. The measurements served a subsequent comparison of tourist traffic intensity in two footpath sections in both Polish and Slovak parts of the study area. The sensors were installed on footpaths leading to the Wołowiec Mt. (2064 m a.s.l.). One sensor was installed on the footpath from the Jamnicka Pass to the Wołowiec Mt. (Slovak part) and the other on the footpath from the Pass Below Wołowiec to the Wołowiec Mt. (Polish part) (Fig. 1).

\section{SLOPE TRANSFORMATION WITHIN FOOTPATHS ABOVE THE TIMBERLINE}

The diversity of climatic conditions and the number of tourists play an important role in the transformation of relief in within footpaths in different slope sections. The disproportion in the numbers of tourists between the Polish and Slovak parts of the Tatra Mountains was highlighted by M. Š tur c el (2006). His calculations of differences in tourist traffic on $1 \mathrm{~km}$ of footpaths in the Tatra National Park (TNP) showed it is three times more intense in its Polish part than in the Slovak part. This is also confirmed by this study, conducted in the alpine belt in the Polish and Slovak parts of the TNP using tourist counters. From June to August 2011 the average daily number of tourists in the Slovak part of the TNP on the footpath section from the Jamnicka Pass to the Wołowiec Mt. was 82 compared to 
the daily average of 354 persons on the footpath from the Pass Below Wolowiec to the Wolowiec Mt. in the Polish part of the TNP.

Tourist traffic is an important factor that by trampling of vegetation and soil cover contributes to the acceleration of natural morphogenetic processes, such as run-off, needle-ice activity, nivation and deflation. These processes result in the development of numerous erosive and accumulation forms and successive expansion of degraded areas on slopes with footpaths (K r z e m i en 1997, 2008; Gorczyca, Krzemień 2002, 2010; Rą czkowska, Kozłowska 2002, 2010). Tourists play a particularly significant role in the transformation of slope relief within footpaths during snowmelt and summer rainfall ( $\mathrm{K}$ a p a 1980).

The environment of the Tatra Mountains above the timberline is particularly vulnerable to relief transformation, which results from both greater diversity and increased activity of natural processes (K o t a r b a 1984, 2002; K r z e m i en $2008,2010)$. In the study area, $6,5 \mathrm{~km}$ of footpaths on slopes exhibit significant relief transformation. The development of erosive and accumulation forms depends mainly on the type of bedrock, slope gradient, as well as the morphological location of the footpath within the slope.

The most important factor in relief transformation is the resistance of geological structure of the slopes underlying footpaths. However, even though all the footpaths in the study area run on crystalline bedrock, there are significant differences between footpath sections. In the study area $91 \%$ of footpaths on slopes have natural surface, while the surface of the remaining $9 \%$ is artificial (usually arranged boulders). Footpaths on slopes with natural surface considerably differ in terms of the dominant size of rock particles in the regolith. The type of slope cover influences development of different erosive landforms and the intensity of relief transformation within the footpath. In the study area I distinguished several types of slope surface with different forms and relief transformation (Tab. 2). For example, study footpaths where particles within regolith cover are smaller than $2 \mathrm{~cm}$ are associated with the development of nival, deflation or crionival niches, while regolith covers with grain-size exceeding $10 \mathrm{~cm}$ are conducive to the development of proluvial fans (Fig. 3; Photo $1 \mathrm{a}$, b, c, d). The occurrence of different types of natural surfaces depends mostly on slope gradient and morphological location. The footpath sections on slopes with high gradients are characterised by a larger grain-size of regolith material than the footpaths on less steep slopes.

In the study area, $53 \%(23 \mathrm{~km})$ of footpaths run on slopes with regolith typified by particle size smaller than $10 \mathrm{~cm} ; 19 \%$ of the footpaths $(9 \mathrm{~km})$ run on slopes with finer regolith $(<2 \mathrm{~cm})$ and $14 \%(6 \mathrm{~km})$ of footpath sections are located on slopes with coarser regolith $(>10 \mathrm{~cm})$. The smallest part $(4 \%$ or $2 \mathrm{~km}$ ) of footpath sections with natural surface are footpaths within bedrock. The remaining footpaths are surfaced with artificially arranged material. Often, particular type of natural surface within footpaths on slopes represents a stage 
Table 2

Diversity of regolith covers within footpaths on slopes in the study area

\begin{tabular}{|c|c|c|}
\hline $\begin{array}{l}\text { Dominant type of natural } \\
\text { surface within footpaths } \\
\text { on slopes }\end{array}$ & Type of landforms & $\begin{array}{l}\text { Examples of footpath sections in } \\
\text { the study area }\end{array}$ \\
\hline $\begin{array}{l}\text { A. soil covers and regolith } \\
\text { with a dominant grain- } \\
\text { size: } \\
<2 \mathrm{~cm}\end{array}$ & $\begin{array}{l}\text { rills, nival niches, deflation } \\
\text { niches, cryonival niches }\end{array}$ & $\begin{array}{l}\text { footpath on the Czubik, footpath } \\
\text { in the Gáborova Valley, footpath } \\
\text { from the Jamnicka Valley to the } \\
\text { Žarska Pass }\end{array}$ \\
\hline \multicolumn{3}{|c|}{ B. regolith with a dominant grain-size: } \\
\hline$<10 \mathrm{~cm}$ & $\begin{array}{l}\text { rills, nival niches, deflation } \\
\text { niches, cryonival niches, } \\
\text { proluvial fans }\end{array}$ & $\begin{array}{l}\text { footpath to the Trzydniowiański } \\
\text { Wierch, the Wołowiec, footpath } \\
\text { from the Jamnicka Pass to the } \\
\text { Ostrý Rohač }\end{array}$ \\
\hline$>10$ & proluvial fans & $\begin{array}{l}\text { footpath to the Starorobociański } \\
\text { Wierch, Kończysty Wierch Mt., } \\
\text { the Plačlivy Rohač }\end{array}$ \\
\hline C. bedrock & - & footpath on the Ostrý Rohač \\
\hline
\end{tabular}

in relief transformation, in the course of which bedrock will eventually be exposed in the footpath floor.

The type of bedrock plays the most important role in relief transformation. However, in the study area there are footpath sections located very close to each other, running over similar rock type, but with significant differences in relief transformation. Those differences may result from differing morphological position of the footpaths. Examples of such footpaths are the section to the Trzydniowiański Wierch or the section near the top of Czubik. The footpath section leading to the top of the Trzydniowiański Wierch is located along the slope gradient and is the most transformed slope section in the study area. The width of the degraded zone is $15 \mathrm{~m}$. Moreover, based on previous research conducted by M. Kr u s i e c (1996), it is worth mentioning that slope relief transformation within the footpath to the Trzydniowiański Wierch has been progressive. On the other hand, the footpath section near the top of Czubik, located perpendicular to slope gradient, is about $1 \mathrm{~m}$ wide and lacks significant relief transformation. These footpath sections also differ in surface type. The footpath to the Trzydniowiański Wierch runs on regolith with rock particles smaller than $10 \mathrm{~cm}$, while in the case of the Czubik footpath the dominant grain-size is $<2 \mathrm{~cm}$. This may have resulted from the activity of morphogenetic processes. Different bedrock resistance, type of covers and the morphological location of the footpaths on the slope, as well as the intensity of human activity all have an impact on the size and extent of progressive relief transformation. 


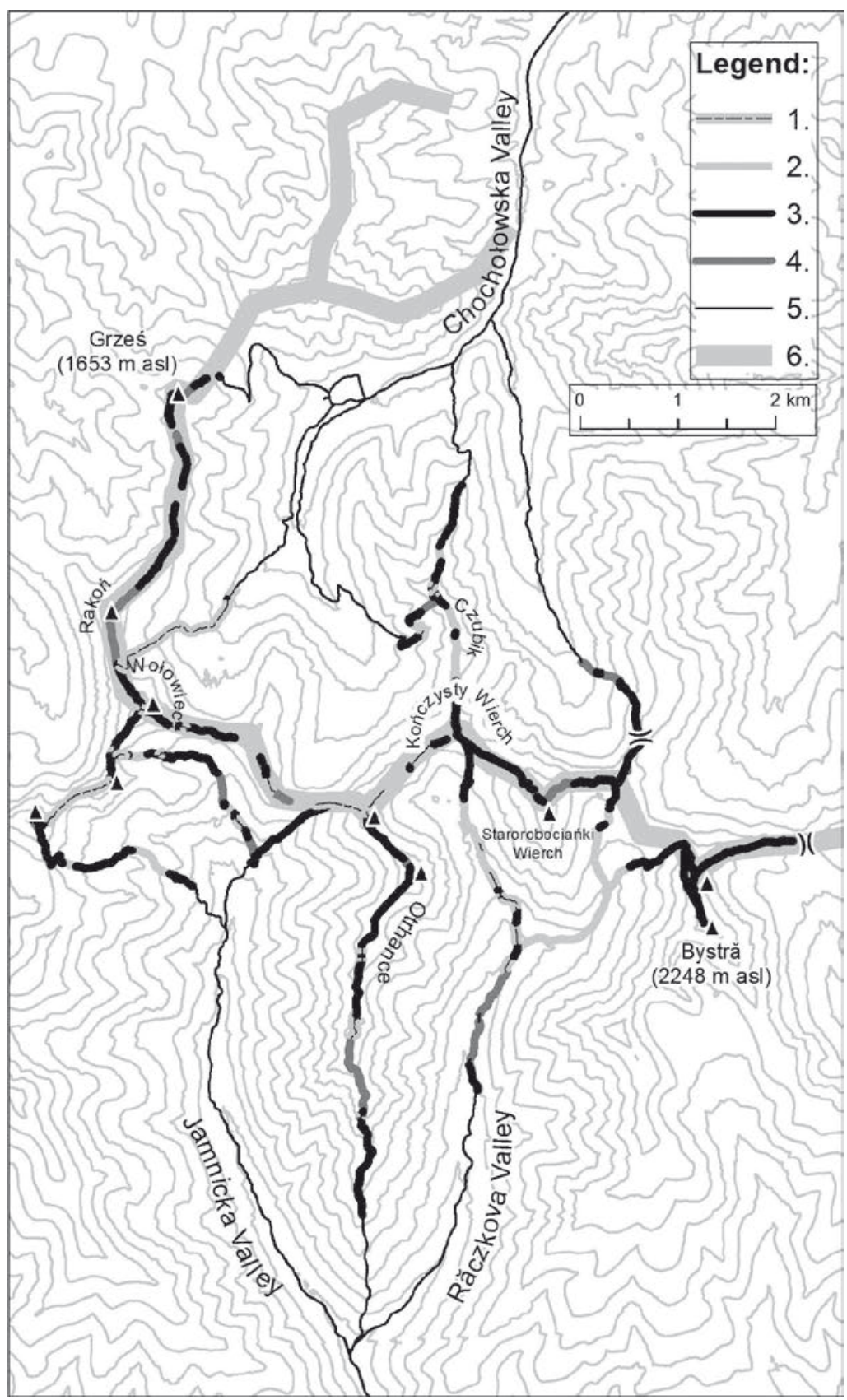

Fig. 3. Diversity of surface types within footpaths in the study area. 1. footpaths on bedrock and artificial surfaces (arranged boulders), 2. footpaths on soil and regolith covers with dominant grain-size of rock material $<2 \mathrm{~cm}, 3$. footpaths on regolith covers with dominant grain-size of rock material $<10 \mathrm{~cm}, 4$. footpaths on regolith covers with dominant grain-size of rock material $>10 \mathrm{~cm}$, 5 . other footpaths, 6 . main ridge 

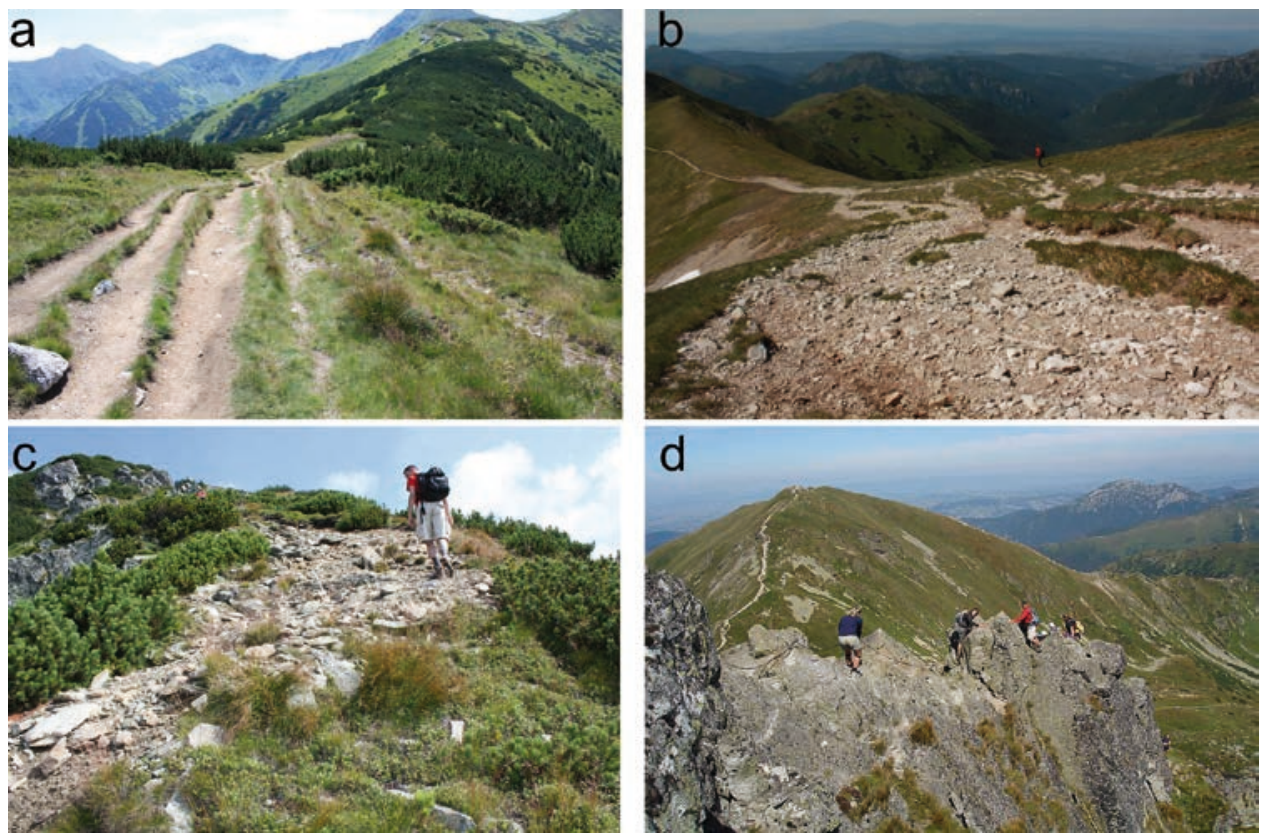

Photo 1. Regolith cover exposed in the ridge section of the footpath to Rakon (a). Regolith cover with a dominance of smaller $(<10 \mathrm{~cm})$ rock particles: the footpath to the Starorobociański Wierch (b). Regolith cover with a dominance of coarse $(>10 \mathrm{~cm})$ rock particles within the footpath on the ridge of Otrhance (c). Bedrock footpath on top of the Ostrý Rohač (d)

\section{RELIEF TRANSFORMATION WITHIN FOOTPATHS ON THE SLOPES ABOVE THE TIMBERLINE}

Detailed studies, conducted on test surfaces located above the timberline, have shown that there are considerable differences in slope relief transformation within footpaths and on slopes without human activity, and that these surfaces represent two different types. The differences in the functioning of these slopes are mainly related to the extent and activity of morphogenetic processes. The complex morphology of the slopes above the timberline causes differences in humidity and thermal conditions between the north- and the south-facing slopes. The south-facing slopes are more intensively transformed in the autumn season, especially when the snow cover appears for short periods and melts. Autumn is also the season of significantly increased needle-ice activity. However, the north-facing slopes are more intensely transformed in the spring thaw season, associated with the extended duration of snow cover and significant activity of nivation. In addition, the northern part of the study area is characterized by larger amounts of precipitation, which contributes to more intense relief transformation caused by run-off. In the study area there are significant differences in the course of natural processes acting on slopes with footpaths and on 
slopes without human activity. These differences are connected with the spatial diversity of processes. On slopes without human activity the natural processes occur evenly, resulting in equal transformation of the whole area devoid of vegetation. On slopes with footpaths, morphogenetic processes occur linearly. The slopes without human activity are characterized by the presence of rubble that increases the resistance of the slope surface to morphogenetic processes. On the other type of slopes, the most visible effect of run-off within footpaths is connected with the movement of rock fragments and local development of shallow rills. In addition, needle-ice action has a significant impact, especially in the marginal parts of the footpaths, which contributes to the development of erosive niches within slopes The highest rate of depth change $(1 \mathrm{~cm} /$ year) was recorded on a test surface located within a footpath that runs in the alpine belt on a north-facing slope. In the southern part of the study area, the highest rate of $0.89 \mathrm{~cm} /$ year was recorded within a footpath on a slope in the subalpine belt.

Numerous studies in the Tatra Mountains, the Alps, the Rocky Mountains, as well as in the Monts Dore in France confirmed that the issue of tourist degradation is a very important problem ( $\mathrm{Ham} \mathrm{m} \mathrm{itt,} \mathrm{J} \mathrm{e} \mathrm{well} \mathrm{2000;} \mathrm{G} \mathrm{o} \mathrm{r} \mathrm{c} \mathrm{z} \mathrm{y} \mathrm{c} \mathrm{a,}$ Krze mi eń 2002, 2010; $\mathrm{M}$ i h a i et al. 2009). To limit tourist traffic-related transformation of slope relief within footpaths an accurate inventory of geomorphological forms and subsequent repeated monitoring of their state is necessary.

\section{CONCLUSIONS}

Nowadays the slopes in high mountain areas are most intensely transformed within footpaths. This is associated with the combined effects of natural processes and anthropogenic impact on these surfaces.

In the study area the footpaths on slopes differ in the type of slope cover which determines the development of certain erosive and accumulation forms.

There are differences between the extent and activity of natural processes on slopes with footpaths and the slopes without any human activity. The research has shown that these two surfaces function differently.

In the Polish and Slovak parts of the Tatra National Park there is an asymmetry related to the intensity of tourist traffic and in the natural conditions, which in turn controls the intensity of natural processes and transformation of slope relief within footpaths.

\section{ACKNOWLEDGEMENTS}

My research was possible in part by a grant from the Ministry of Science and Higher Education, which allowed me to purchase one tourist counter. Other sensors have been provided by the Tatra National Park. I would also like to thank the volunteers from the Tatra National Park. 
Joanna Fidelus

Institute of Geography and Spatial Management

Jagiellonian University

Gronostajowa 7, 30-387 Kraków, Poland

asiafidelus@gmail.com

\section{REFERENCES}

Cole D. N., 1983. Assessing and Monitoring Backcountry trail Conditions. Research paper INT-303. U.S. Department of Agriculture, Forest Service, Intermountain Research Station, Ogden, Utah, $1-10$.

G orczyc a E., Krze mi é K., 2002. Wpływ ruchu turystycznego na rzeźbę Tatrzańskiego Parku Narodowego. [in:] Przemiany środowiska przyrodniczego Tatr. W. Borowiec, A. Kotarba, A. Kownacki, Z. Krzan, Z. Mirek (eds.), Wydawnictwo TPN, Kraków-Zakopane, 389-394.

G o r c z y c a E., Kr z e mi e ń K., 2010. Rola dróg i ścieżek turystycznych w modelowaniu rzeźby gór strefy umiarkowanej. Roczniki Bieszczadzkie 18, 228-242.

$\mathrm{H}$ a m m it t W., J e w ell M., 2000. Assessing soil erosion on trails: A comparison of techniques. USDA Forest Service Proceedings5, 133-140.

H e s s M., 1974. Piętra klimatyczne Tatr. Czasopismo Geograficzne 45, 75-93.

I $\mathrm{z}$ m a i ło w B., 1984. Eolian deposition above the upper timber line in the Gasienicowa Valley in the TatraMts. Prace Geograficzne UJ 61, 43-59.

K a s z o w s k i L., 1985. Rzeźba i modelowanie gór wysokich strefy suchej na przykładzie Hindukuszu Munjan. Rozprawy Habilitacyjne UJ 94, 191 pp.

Kła pa M., 1980. Procesy morfogenetyczne oraz ich zwiąek z sezonowymi zmianami pogody $w$ otoczeniu Hali Gąsienicowej $w$ Tatrach. Dokumentacja Geograficzna IGiPZ PAN 4, 1-53.

K o t a r b a A., 1976. Wspótczesne modelowanie węglanowych stoków wysokogórskich. Prace Geograficzne IGiPZ PAN 120, 114 pp.

K o t a r b a A., 1984. Elevation differentation of slope geomorphic processes in the Polish Tatra Mountains. Studia Geomorphologica Carpatho-Balcanica, 18, 117-132.

K o t a r b a A., 1992. Natural environment and landforms dynamics of the Tatra Mountains. Mountain Research and Development 12, 2, 105-129.

Kotarba A., 2002. Współczesne przemiany przyrody nieożywionej $w$ Tatrzańskim Parku Narodowym. [in:] Przemiany środowiska przyrodniczego Tatr. W. Borowiec, A. Kotarba, A. Kownacki, Z. Krzan, Z. Mirek (eds.), Wydawnictwo TPN, Kraków-Zakopane, 13-19.

K ot arba A., Dłu g os z M., 2010. Alpine cliff evolution and debris flow activity in the High Tatra Mountains. Studia Geomorphologica Carpatho-Balcanica 44, 35-47.

Kotarba A., Starkel L., 1972. Holocene morphogenetic altitudinal zones in the Carpathians. Studia Geomorphologica Carpatho-Balcanica 6, 21-35.

Krusiec M., 1996. Wpływ ruchu turystycznego na przekształcanie rzeźby Tatr Zachodnich na przykładzie Doliny Chochołowskiej. Czasopismo Geograficzne 67, 303-320.

Krz e mi eń K., 1997. Morfologiczne skutki gospodarki turystycznej w obszarze wysokogórskim na przykładzie masywu les Monts Dore (Francja). [in:] Geografia człowiek gospodarka. B. Domański (ed.), Wydawnictwo IGiGP UJ, Kraków, 277-286.

K r z e m i e ń K., 2008. Contemporary landform development in the Monts Dore Massif, France. Geographia Polonica 81, 1, 67-78.

Krz e mi eń K., 2010. Les transformations contemporaines du relief du massif du Mont-Dore. [in:] Developpment durable des territories: de la mobilisation des acteurs aux demarches participatives. D. Ricard D (ed.), Clermont-Ferrand, 353-378.

Łajczak A., 2006. Przestrzenne zróżnicowanie zasobów wodnych Tatr na tle innych gór. [in:] Tatrzański Park Narodowy na tle innych terenów chronionych. t. 1, A. Kotarba, W. Borowiec (eds.), Wydawnictwo TPN, 19-35. 
Mihai B., Reynard E, Werren G., S avule scu I., S andric I., Chitu Z. 2009. Impacts of tourism on geomorphological processes in the Bucegi Mountains in Romania. Geographica Helvetica 64, 3, 134-147.

Mi d ri a k R., 1983. Morfogeneza pourchuvysokychpohori. Veda, Bratysława, 516 pp.

Midriak R., 1996. Present-day processes and micro-landforms evaluation: case study of Kopske Sedlo, the Tatra Mountains, Slovakia. Studia Geomorphologica Carpatho-Balcanica 30, 39-50.

Ni e dźwi e dź T., 1992. Climate of the Tatra Mountains. Mountain Research and Development 12, $2,131-146$.

Pociask-Karte czka J., B a ścik M., Czubernat S., 2008. Ruch turystyczny $w$ Tatrzańskim Parku Narodowym w latach 1993-2005. [in:] Studia nad turystyka. Tradycje stan obecny i perspektywy badawcze. t. 1, W. Kurek, M. Mika (eds.), Wydawnictwo IG i GP UJ, Kraków, 271-279.

Rą c z k ow s k a Z., 1999. Rzeźba stoków w otoczeniu Kasprowego Wierchu. Prace Geograficzne IG i PZ PAN 174, 17-24.

Rą c zkowska Z., 2007. Współczesna rzeźba peryglacjalna wysokich gór Europy. Prace Geograficzne IG i PZ PAN 212, 252 pp.

Rą c zkowska Z., Kozłowska A., 2002. Odzwierciedlenie wpływów antropogenicznych $w$ wybranych elementach środowiska przyrodniczego otoczenia Kasprowego Wierchu. [in:] Przemiany środowiska przyrodniczego Tatr. W. Borowiec, A. Kotarba, A. Kownacki, Z. Krzan, Z. Mirek (eds.), Wydawnictwo TPN, Kraków-Zakopane, 403-406.

Rą c zkowska Z., Kozłowska A., 2010. Wpływ turystyki na rzeźbę i roślinność przy ścieżkach $w$ otoczeniu Kasprowego Wierchu. [in:] Przyroda Tatrzańskiego Parku Narodowego a Człow$i e k$. Z. Krzan (ed.), Wydawnictwo TPN, Zakopane, 21-28.

Re ch A. J., Re e ve s W. R., He nd ri cks D. M., 2001. The influence of slope aspect on soil weathering processes in the Springerville volcanic field, Arizona. Catena 43, 49-62.

S tankovians ky M., Midriak R., 1998. The recent and present-day geomorphic processes in Slovak Carpathians. Studia Geomorphologica Carpatho-Balcanica 32, 69-87.

S t o c k e r E., 1979. Geomorphological field experiments in the high-alpine regions of the Austrian Alps (with special reference to the Kreuzeckgruppe, Carinthia). Studia Geomorphologica Carphatho-Balcanica 13, 97-110.

S t o c k e r E., 2003. Conditions of alpine gully development as exemplified by the Austrian Alps. Studia Geomorphologica Carphatho-Balcanica 37, 5-27.

Št u r c el M., 2006. Monitoring navštevnosti TANAPu 5-7.08.2004. [in:] Tatrzański Park Narodowy na tle innych górskich terenów chronionych. Z. Krzan, (ed.), Wydawnictwo TPN, Zakopane, $109-115$. 